\title{
Analisa Pengaruh Perkembangan Laba Rugi Bersih Sebelum Pajak Badan terhadap Perkembangan Kas dan Setara Kas Perusahaan Industri Mebel
}

\author{
Irwan Rutlan Atmadireja ${ }^{1}$, Yenia Endriastuty ${ }^{2}$, Daryanto $^{3}$ \\ ${ }^{123}$ STIE Dharma Agung \\ ${ }^{1}$ irwan.rutlan@yahoo.com
}

\begin{abstract}
ABSTRAK
Penelitian ini dilakukan untuk mengetahui deskripsi "Korelasi Antara Laba Bersih Sebelum Pajak atau Laba Sebelum Pajak / EBT dan Setara Kas dan Kas di Perusahaan Manufaktur. Adapun populasi target dalam penelitian ini adalah Kas dan Setara Kas di Perusahaan Industri Mebel Cikarang, Bekasi, Jawa Barat. Sampel yang digunakan dalam penelitian ini adalah 12 sampel total EBT dan Setara dan Tunai dalam 12 bulan. Dalam penelitian ini desain penelitian menggunakan desain cross sectional yang bertujuan untuk menentukan frekuensi dan korelasi variabel independen dan hubungannya dengan variabel dependen. Berdasarkan hasil penelitian, ditemukan bahwa ada hubungan yang signifikan antara EBT dan Cash dan Cash Equivalent dengan nilai koefisien $<0,05$. Hasil penelitian menunjukkan tidak ada hubungan yang signifikan antara tingkat EBT dan Setara dan Tunai di Perusahaan Industri Mebel Cikarang, Bekasi, Jawa Barat.
\end{abstract}

Kata Kunci: Laba Rugi Bersih, Kas, Sentra Kas, Industri Mebel

\section{PENDAHULUAN}

Setiap Pengurus Perusahaan (Direktur atau Manajer) tentunya sangat mengharapkan mengharapkan Laba (keuntungan) yang sangat besar karena diharapkan laba tersebut akan menunjang kemakmuran (Wealth) perusahaan, jika perusahaan sudah makmur tentunya akan membuat para Pemilik Perusahaan (Stake Holder) sangat senang, sehingga pastinya mereka akan memutuskan untuk melanjutkan Usaha mereka tersebut.

Akan tetapi selain Laba, ada komponen lainnya yang juga tidak kalah penting, yaitu Perkembangan uang perusahaan atau yang secara umum disebut oleh para Praktisi Akuntansi dan Auditor sebagai "Kas dan Setara Kas (Cash dan Cash Equivalent)".

Kas dan Setara Kas adalah komponen Aset (Harta/Assets) yang sangat penting, karena untuk membayar Utang, Beban-beban (Biayabiaya/Expenses) dan membeli Aset-aset baru (seperti penambahan mesin-mesin produksi ataupun kendaraan-kendaraan baru untuk mengirim barang), oleh karena itu sangat disayangkan jika para Pengurus Perusahaan yang dibantu para staf nya sangat memperhatikan perkembangan laba, tetapi tidak memperhatikan perkembangan Kas dan Setara kas.

Pada penelitian ini, yang menjadi objek penelitian adalah PT. Aditera Sarana Prima yang merupakan perusahaan yang memproduksi sarana dan prasarana Kantor, Pabrik dan Gudang sesuai pesanan, seperti Meja, Kursi, Sofa, Lemari, Rak Gudang, dll. Yang pada awalnya perusahaan ini cukup menjanjikan dalam hal memperoleh laba nya dan pada kenyataannya pernah mengalami kerugian pada bulan Desember 2016, karena kerugian tersebut tidak terlalu besar, maka sampai dengan saat ini PT. Aditera Sarana Prima masih beroperasi dengan lancar walaupun terkadang pernah sedikit mengalami defisit kas yang berakibat penundaan pembayaran Utang Usaha (pembelian bahan baku).

\section{METODE PENELITIAN}

Penelitian dilakukan pada Perusahaan Industri Mebel yang berlokasi di Jl. Cilemah Abang No.10, Jayamukti, Kec. Cikarang Pusat, Bekasi, Jawa Barat 17530. Desain penelitian yang digunakan adalah cross sectional yaitu seluruh variable independen dan dependen diamati dalam satu periode tertentu dan dalam satu populasi. Desain cross sectional ini dipilih untuk mengetahui hubungan antara 
perkembangan Laba Rugi Bersih sebelum Pajak dan Kas dan Setara kas.

Dimensi survei digunakan dalam penelitian ini untuk mengumpulkan data yang relevan dan dari total jumlah populasi sebanyak 12 bulan, data-data yang diambil adalah hasil perhitungan Laba Rugi Bersih sebelum Pajak setiap bulannya (data diambil dari Laporan Laba Rugi Komprehensif bulanan) dan hasil perhitungan total perubahan Kas dan Setara kas karena Aktivitas Operasional (data diambil dari Laporan Arus Kas bulanan).

Sedangkan Skema kerangka konsep penelitian dapat digambarkan sebagai berikut:

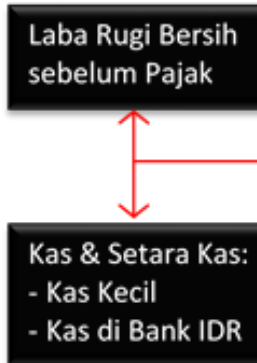

Gambar 1. Skema Kerangka Konsep Penelitian

\section{HASIL DAN PEMBAHASAN}

Berikut ini adalah Laba Rugi Bersih sebelum Pajak dan perubahan Arus Kas dan Setara Kas karena Aktivitas Operasional PT. Aditera Sarana Prima periode Juli 2016 sampai dengan Juni 2017. Data di ambil dari Laporan Laba Rugi Komprehensif untuk data bulanan Laba Rugi sebelum Pajak, sedangkan Laporan Arus Kas untuk data bulanan Kas dan Setara Kas. Seperti pada table 1 yang angka-angka tersebut disajikan dalam ribuan rupiah.

Tabel 1. Laporan Arus Khas untuk Data Bulanan Kas dan Setara Kas

\begin{tabular}{ccc}
\hline & Laba (Rugi) & Cash \\
\hline Jul-16 & 215,679 & 95,706 \\
\hline Aug-16 & 195,300 & 87,500 \\
\hline Sep-16 & 170,500 & 90,500 \\
\hline Oct-16 & 182,750 & 50,210 \\
\hline Nov-16 & 150,751 & 43,970 \\
\hline Dec-16 & $(12,450)$ & 35,710 \\
\hline Jan-17 & 34,890 & 31,650 \\
\hline Feb-17 & 154,670 & 10,450 \\
\hline Mar-17 & 189,112 & 9,145 \\
\hline Apr-17 & 114,567 & 34,512 \\
\hline
\end{tabular}

\begin{tabular}{ccc}
\hline May-17 & 108,765 & 68,890 \\
\hline Jun-17 & 256,987 & 103,850 \\
\hline Total & $\mathbf{1 , 7 6 1 , 5 2 1}$ & $\mathbf{6 6 2 , 0 9 3}$ \\
\hline Average & $\mathbf{1 4 6 , 7 9 3}$ & $\mathbf{5 5 , 1 7 4}$ \\
\hline
\end{tabular}

Dan berikut hasil perhitungan Analisa Regresi dengan menggunakan Aplikasi SPSS;

Tabel 2. Hasil Hitung Anova

\begin{tabular}{cccc}
\multicolumn{4}{c}{ ANOVA $^{\text {a }}$} \\
\hline & Model & Sum of Squares & df \\
\hline 1 & Regression & 15972903069 & 1 \\
\hline & Residual & 47356821279 & 10 \\
\hline & Total & 63329724349 & 11 \\
\hline
\end{tabular}

a. Dependent Variabel: Laba Bersih

b. Predictirs: (Constant), Kas

\begin{tabular}{ccc}
\hline Mean Square & F & Sig \\
\hline 15972903069 & 3.373 & $.096^{\mathrm{b}}$ \\
4735682128 & & \\
\hline
\end{tabular}

Berdasakan hasil perhitungan tersebut di atas, Sig $=0,96$ atau lebih kecil dari 0,2 jadi dapat disimpulkan bahwa hubungan perkembangan Laba Bersih sebelum Pajak dengan perkembangan Kas \& Setara kas sangatlah rendah.

Tabel 3. Koefisien Kas dan Setara Kas

\begin{tabular}{llrr}
\hline \multirow{2}{*}{ Model } & \multicolumn{2}{c}{ Unstandardized coefficients } \\
\cline { 3 - 4 } & & \multicolumn{1}{c}{ B } & \multicolumn{1}{c}{ Std. Error } \\
\hline 1 & (Constant) & 83457.137 & 39799.171 \\
& Kas & 1.148 & .625 \\
\hline
\end{tabular}

\begin{tabular}{|c|c|c|}
\hline$\frac{\text { Standardized Coefficients }}{\text { Beta }}$ & $\mathrm{t}$ & Sig \\
\hline & 2.097 & .062 \\
\hline .502 & 1.837 & .096 \\
\hline
\end{tabular}

Berdasarkan hasil perhitungan koefisiensi, terlihat bahwa Kas \& Setara Kas yang cenderung tetap/konstan (constant) adalah sebesar IDR 83.457,137 (sedangkan rata-rata Kas \& Setara Kas adalah IDR 55.174) dan yang cenderung berubah-ubah adalah hanya sebesar IDR 1.148,untuk setiap IDR 1,- perubahan Laba Bersih.

\section{KESIMPULAN}

Sesuai dengan hasil pembahasan, dapat disimpulkan, bahwa perkembangan Laba Bersih 
setelah Pajak sangat lemah pengaruhnya terhadap perkembangan Kas \& Setara kas, atau dengan kata lain jika Laba Bersih sebelum Pajak bertambah, kecil kemungkinannya Kas \& Setara kas juga ikut bertambah bahkan bias dibilang Kas \& Setara kas akan cenderung tetap atau tidak berubah, hal ini dapat mengakibatkan semangat untuk menghasilkan laba semakin kecil, karena para Pengurus Perusahaan menyadari bahwa meningkatkan Laba akan percuma karena tidak akan meningkatkan Kas \& Setara Kas.

Menurut Teori Akuntansi, ada beberapa penyebab perkembangan Laba Bersih sebelum Pajak tidak mempengaruhi perkembangan Kas \& Setara Kas, yang pertama adalah terlalu banyak Penjualan Secara Kredit dan penerapan Penagihan Piutang nya sangat lemah dan yang kedua adalah Utang Usaha yang dilunasi atau yang dibayarkan sangat banyak pada periodeperiode tersebut.

\section{DAFTAR PUSTAKA}

Donald E. Kieso, Jerry J. Weygandt, \& Terry D. Warfield. (2013). Accounting Principles 11th. New York, United States of America, John Wiley \& Sons, Inc.

Donald E. Kieso, Jerry J. Weygandt, \& Terry D. Warfield. (2016). Accounting Intermediate 16th. New York, United States of America, John Wiley \& Sons, Inc.

Steven C. Huchendorf, Dawn C. Porter, \& Patrick J. Schur. (2009). Business Statistic in Practice 8th. New York, California, United States of America, McGraw-Hill/Irwin.

William N. Lanen, Shannon W. Anderson, \& Michael W. Maher. (2016). Fundamentals Cost Accounting 4e, California, United States of America, McGraw-Hill/Irwin. 